Review ARticle

\title{
Advances in the knowledge of amphizoic amoebae infecting fish
}

\author{
Iva Dyková ${ }^{1,2}$ and Jiří Lom ${ }^{1}$ \\ ${ }^{1}$ Institute of Parasitology, Academy of Sciences of the Czech Republic, Branišovská 31, 37005 České Budějovice, Czech \\ Republic; \\ ${ }^{2}$ Faculty of Biological Sciences, University of South Bohemia, Branišovská 31, 37005 České Budějovice, Czech Republic
}

Key words: amphizoic amoebae, fish hosts, Acanthamoeba, Cochliopodium, Filamoeba, Naegleria, Neoparamoeba, Nuclearia, Platyamoeba, Thecamoeba, Vannella, Vexillifera

\begin{abstract}
Free-living amoebae infecting freshwater and marine fish include those described thus far as agents of fish diseases, associated with other disease conditions and isolated from organs of asymptomatic fish. This survey is based on information from the literature as well as on our own data on strains isolated from freshwater and marine fish. Evidence is provided for diverse fish-infecting amphizoic amoebae. Recent progress in the understanding of the biology of Neoparamoeba spp., agents responsible for significant direct losses in Atlantic salmon and turbot industry, is presented. Specific requirements of diagnostic procedures detecting amoebic infections in fish and taxonomic criteria available for generic and species determination of amphizoic amoebae are analysed. The limits of morphological and non-morphological approaches in species determination are exemplified by Neoparamoeba, Vannella and Platyamoeba spp., which are the most common amoebae isolated from fish gills, Acanthamoeba and Naegleria spp. isolated from various organs of freshwater fish, and by other unique fish isolates of the genera Nuclearia, Thecamoeba and Filamoeba. Advances in molecular characterisation of SSU rRNA genes and phylogenetic analyses based on their sequences are summarised. Attention is particularly given to specific diagnostic tools for fish-infecting amphizoic amoebae and ways for their further development.
\end{abstract}

\section{INTRODUCTION}

Free-living naked amoebae, highly variable and diverse eukaryotic organisms, are ubiquitously distributed in soil and aquatic habitats. They are the main predators controlling bacterial populations in soil. They prevail among protozoans in freshwater bodies and constitute regular components in coastal waters and marine sediments. Amoebae previously considered to be entirely free-living, while also capable of invading host tissues, are referred to as amphizoic (Page 1974). Several species among them have been recognised as serious pathogens of humans, lower vertebrates as well as invertebrates.

The history of basic discoveries in free-living amoebae pathogenic for humans has been well documented in monographs, reviews and introductions to case reports and papers focused on medically important genera Acanthamoeba Volkonsky, 1931, Naegleria Alexeieff, 1912 and Balamuthia Visvesvara, Schuster et Martinez, 1993 (Martinez 1985, Visvesvara and Stehr-Green 1990, Visvesvara et al. 1993, John 1993, Martinez and Visvesvara 1997, De Jonckheere 2002). Water supplies, swimming pools, freshwater ponds, lakes and thermally polluted waters have been surveyed as sources of human infections. However, the attention of the researchers has been limited to the prevalence of amoebae living freely in the water habitats, while the occurrence of amoebae in fish that inhabit an aquatic environment, has been neglected for a long period of time.
Aquaculture, including fish farming, has enjoyed an unprecedented expansion over the last few decades and new technologies have led to a dramatic increase in production. In highly intensive farming systems, diseases play a major role in production levels. Detailed knowledge of causes and combined factors of diseases, as well as research of emerging and potential pathogens, is of paramount importance. In comparison with other fish-infecting eukaryotic microorganisms, amphizoic amoebae have not received enough attention to date. The study of amoebae as potential agents of fish diseases, initiated in the Institute of Parasitology AS CR several years ago, resulted in establishing a large collection of amoeba strains of fish origin and in obtaining new data on the biology of amphizoic amoebae. The purpose of this review is to summarise our own research experience with data available in the literature on this group of true and potential fish pathogens.

\section{METHODICAL APPROACHES TO THE STUDY OF AMPHIZOIC AMOEBAE INFECTING FISH}

Our screening for the presence of amphizoic amoebae in parenchymatous organs and gills of fish has been based on isolation attempts carried out exclusively on agar plates. In order to avoid excessive contamination, tissues of fish brought to the laboratory were sampled

This paper was presented at the 6th International Symposium on Fish Parasites in Bloemfontein, South Africa, 22-26 September 2003. 


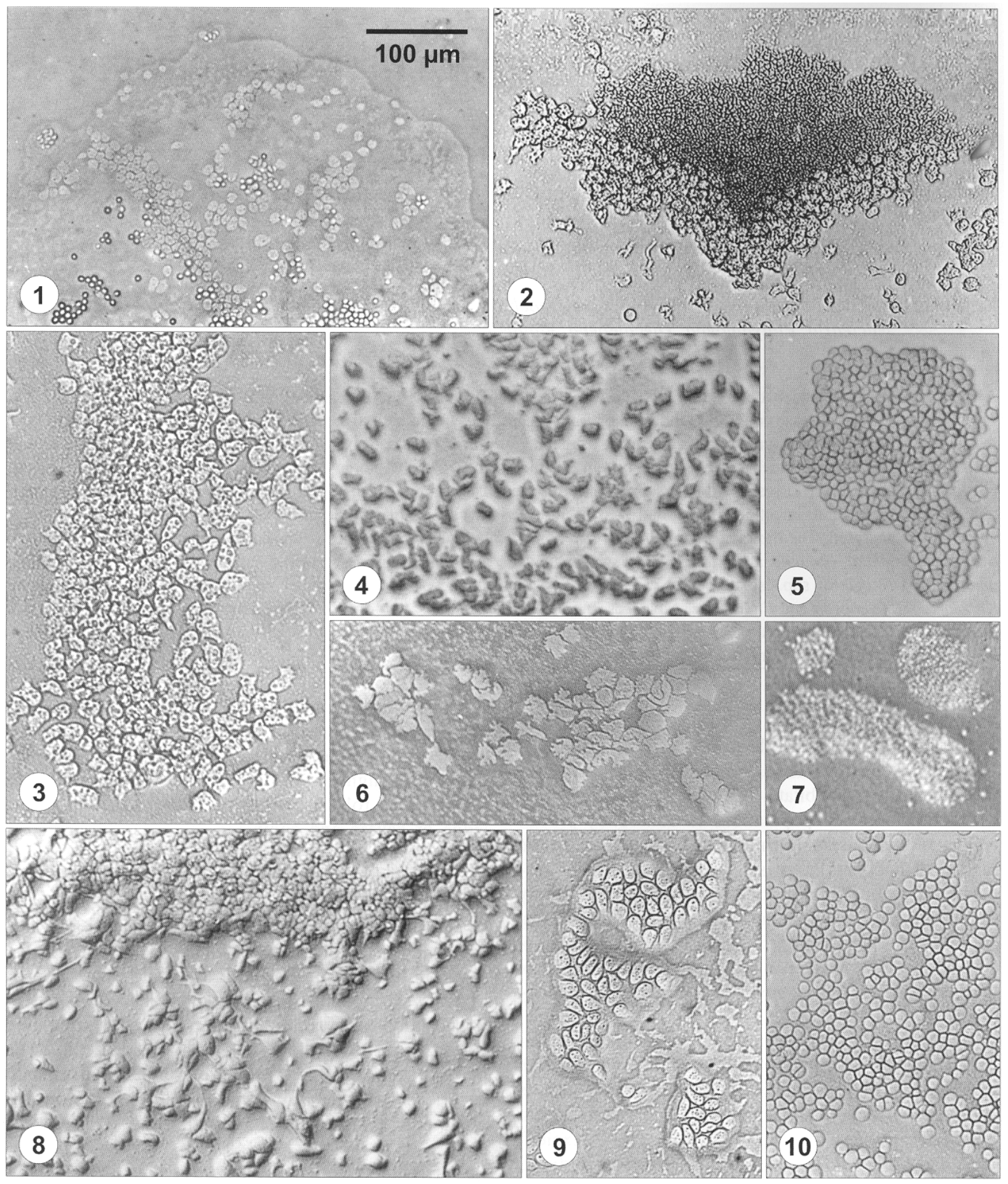

Figs. 1-10. Agar plate cultures of amphizoic amoebae isolated from organs of fish and observed through Petri dishes in translucent light or using the Olympus Nomarski DIC system. Fig. 1. Primary isolate of a cyst-forming amoeba. Trophozoites migrating from decomposing tissue are seen behind the line of bacterial growth. Amoebae transformed into cysts appear as refractile globules. Fig. 2. Initial culture of Hartmannella sp. Trophozoites multiply together with bacterial colony. Fig. 3. The dense zone of growth of highly vacuolated trophozoites of Neoparamoeba sp. Fig. 4. Advanced culture of Vannella sp. Fig. 5. Trophozoites of Platyamoeba sp. transformed in rounded resting stages in a ten-day culture. Fig. 6. Paraflabellula-like trophozoites. Fig. 7. Rosculus ithacus culture. Fig. 8. Flabellula sp. culture. Fig. 9. Aggregates of trophozoites typical of Nuclearia pattersoni. Fig. 10. Rounded stages of Flabellula sp. in old culture. All figures magnified at the same scale. 
with sterile instruments, in laminar-flow boxes. Field sampling has been limited to exceptional situations. If necessary, big pieces of tissues were transferred to the laboratory where adequate-sized samples were excised and placed on non-nutrient agar. Non-nutrient amoeba saline agar (NN) and MY75S agar were prepared as recommended by Page (1988) and Kalinina and Page (1992) and used for primary isolations as well as for subculturing of amoebae. Since the quality (transparency) of agar is of primary importance for observation of amoeba growth, Difco or BD Bacto ${ }^{\mathrm{TM}}$ Agar was used. The content of malt and yeast extracts was reduced (sometimes down to zero) when sampled gills were heavily contaminated with bacteria. Agar plates with decomposing pieces of tissues stored either at room temperature or $20^{\circ} \mathrm{C}$ were checked once a day for up to three weeks for the presence of amoeba trophozoites migrating out from decomposing tissues. Subculturing of isolated amoebae has been carried out basically as described for free-living amoebae by Kalinina and Page (1992). Their procedures have been slightly modified in the course of our studies. Since amoebae isolated from decomposing tissues always contained bacteria and carried them into the cultures, there was no need to seed agar plates with autoclaved bacteria for quite a long period of subculturing. More efficient, i.e., less timeconsuming, was to reduce the growth of bacteria by selection of the amoeba cells in best condition for each subculture than to make attempts first to eliminate bacteria with antibiotics and then start to feed amoebae with autoclaved bacteria. In later stages of clonal subculturing, agar plates were seeded with autoclaved bacterial suspensions. In addition to collection strains of Escherichia coli, Bacillus subtilis or Klebsiella sp., autoclaved mixtures of bacteria isolated together with primary isolates also served as food in later stages of clonal subculturing. Among food organisms, small bacteria (e.g., Pseudomonas spp.) were found best for future observations of the fine structure of trophozoites. The morphology of all amoeba strains obtained as a result of repeated selection of homogeneous cell populations has been documented (Figs. 1-10). Such populations were cryopreserved in order to avoid any loss of species during the clonal isolations. The clones were derived from strains using isolated individual cells cut out with a square-shaped piece of agar and transferred onto fresh agar plate with the side of the block bearing the cell downwards. For axenisation of Acanthamoeba and Naegleria clones, the liquid culture media (bactocasitone [BCS], or Chang's serum-casein-glucose-yeast extract medium [SCGYEM]) were used exclusively.

The observation of living amoebae in hanging drop preparations with the aid of Nomarski differential interference contrast (DIC) proved to be the best among the light microscopical methods (compare Figs. 11-14; see also Figs. 15-28). Staining of fixed cells was found to be useful in Neoparamoeba trophozoites only, which

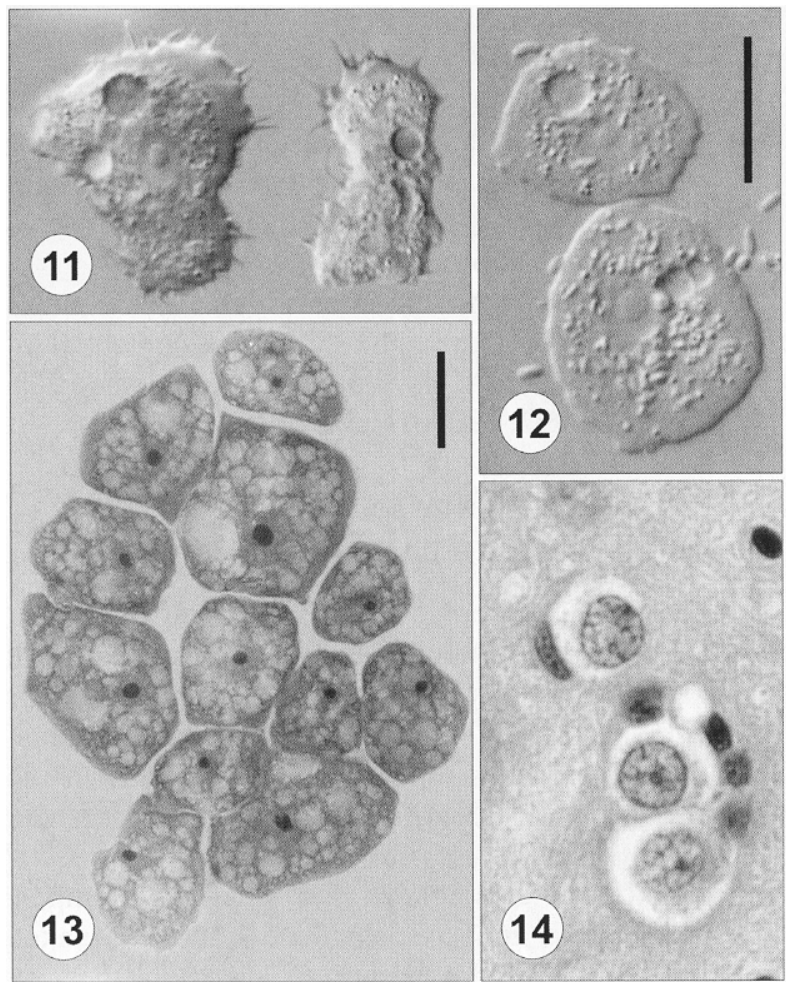

Figs. 11-14. Trophozoites of the same Acanthamoeba strain seen under different conditions. Fig. 11. When observed in hanging drop preparations, live trophozoites exhibit their acanthopodia. Fig. 12. Under the coverslip pressure, trophozoites loose their acanthopodia very fast (both pictures Nomarski DIC). Fig. 13. Fixed and stained trophozoites have no acanthopodia. Fig. 14. Trophozoites in brain tissue of experimentally infected fish, H\&E, $\times 650$. This is their usual appearance in histological sections. Scale bar joint for Figs. 11 and $12=10 \mu \mathrm{m}$; Fig. $13=20 \mu \mathrm{m}$.

harboured endosymbionts detectable with Periodic Acid Schiff (PAS) reaction, fluorescent dyes or even with haematoxylin and eosin (H\&E) (Dyková et al. 2003a).

Transmission electron microscopy was routinely used in morphological characterisation of clonal material. Trophozoites and cysts of individual clones were always fixed in situ (on the surface of agar plates) with $2.5 \%$ sodium cacodylate buffered glutaraldehyde and then pelleted for postfixation with $1 \%$ osmium tetroxide. Epon-Araldite, and more recently Spurr's resin, were used for embedding. Fixation with ruthenium red has been successfully applied in order to improve resolution of glycocalyx (Hopwood and Milne 1991).

Of the non-morphological methods, molecular characterisation of clones based on small subunit (SSU) rRNA gene sequences, used for phylogenetic analyses, were included in our study of amphizoic amoebae in the first place. The restriction fragment length polymorphism-PCR analysis of SSU rRNA genes (riboprints) of 
Naegleria strains was performed using restriction enzymes AluI and Hinfl (Dyková et al. 2001). Fluorescent in situ hybridisation (FISH) analysis was used when testing sequences of Acanthamoeba strains of fish origin (Dyková et al. 1999a). We currently combine morphological and non-morphological methods in the process of amoeba identification.

A limited number of experiments were carried out to date in order to recognise the pathogenic potential of amoebae isolated from asymptomatic freshwater fish (Dyková et al. 1997, 1998b, Veverková et al. 2002).

\section{TAXONOMIC CRITERIA AND CLASSIFICATION OF AMPHIZOIC AMOEBAE}

The taxonomic criteria available for generic and species determination of amphizoic amoebae isolated from organs of fish are naturally the same as described for free-living species. They correspond to fundamental methodical approaches that can be traced back in the history of species identification within the genera Acanthamoeba and Naegleria.

Morphological characteristics of diagnostic importance for generic and species identification of naked amoebae can be found in monographs published by Page (1987, 1988, 1991), which have been generally adopted in subsequent descriptions of new species. The system of morphotypes developed as a tool for preliminary determination of naked amoebae by Smirnov and Goodkov (1999) is considered more helpful in ecological studies than in species diagnosis of pathogenic or potentially pathogenic agents.

The range of morphological characters suitable for generic diagnosis of isolated amoebae is rather limited. Only several genera can be recognised in the light microscope. Nomarski DIC is more instructive than conventional light or phase contrast microscopy in recording morphology of trophozoites (Figs. 15-28) and cysts (Figs. 29-37). The study of ultrastructural details significantly contributes to the morphological characterisation of isolated amoebae. Among ultrastructural features that are helpful in generic diagnosis, the most important is the appearance of mitochondrial cristae (Figs. 38-49), endoplasmic reticulum and Golgi apparatus configuration (Figs. 50-52), details of glycocalyx differentiation (Figs. 53-61), nuclear envelope and types of nuclear division of trophozoites. The specific endosymbionts, e.g., those described in genera of the family Paramoebidae rank among unique features. Of the non-morphological approaches to the identification of amoebae, the use of isoenzyme patterns (valuable in identification of many protozoa) has been restricted to axenically grown cultures since Weekers and De Jonckheere (1997) observed that the correct isoenzymatic typing can be influenced by the bacterial substrate. The differences in zymograms between axenically and monoxenically grown amoebae appeared to be greater than those among different strains (De Jonckheere 1983,
1988, Pernin et al. 1985). The development of molecular techniques aimed at recognition of genetic diversity and phylogenetic relationships among eukaryotic organisms also strongly influenced studies of free-living amoebae. Molecular markers, mainly the SSU rRNA gene sequences have been used to identify species that are impossible to determine by morphological study. Partial SSU rRNA gene sequences allowed the characterisation of morphologically indistinguishable strains within the genera Acanthamoeba and Naegleria. To date, 24 Naegleria species have been described using a variety of different methods and description in print of another 11 species have been reported by De Jonckheere (2003). All 35 species can be identified on the basis of their internal transcribed spacer (ITS) rDNA sequences. The same applies to vahlkampfiid species other than Naegleria. The 18S rRNA gene-derived phylogeny of Acanthamoeba strains used to improve the taxonomy of the genus allowed distinguishing several sequence types within the most common group of strains (MG2) characterised by the same type of cyst (Gast et al. 1996, Stothard et al. 1998, Schroeder et al. 2001).

In contrast with advanced molecular studies of the genera mentioned above, the taxonomic criteria available for generic and species determination of naked amoebae other than Acanthamoeba and Naegleria are still based mainly on morphology. Except for Acanthamoeba and Naegleria strains, species representatives of 27 genera only have been sequenced to date.

Comparative analysis of the small subunit ribosomal RNA gene sequences, which determine evolutionary relatedness between organisms, has been recognised as the most consistent and comprehensive approach to systematic classification using molecular data (Medlin et al. 1998, Sogin and Silberman 1998). Nevertheless, from a purely taxonomic standpoint, no well-developed criteria exist for protozoans to establish species solely on the basis of nucleotide sequence data (Sogin 1990). While the identity of SSU rRNA gene sequences can infer the identity of species (especially when the sequence of type strain is included), the sequence differences are difficult to interpret in a taxonomic context.

Although the exact recognition of amoebae that can possibly cause fish diseases is extremely important, the taxonomic criteria applicable for naked amoebae at the generic and subgeneric level are not sufficient for all genera involved.

Several classification systems have been proposed since the class Rhizopoda von Siebold, 1845 was established as an independent group among Protozoa. Historically, the first system was based on morphological characters apparent at the light microscopical level (Singh 1952, Honigberg et al. 1964). Ultrastructural data of taxonomic significance, which were employed by Page (1976), were also used in the classification of Protozoa by Levine et al. (1980). Since that time, the number and reliability of taxonomic characteristics have 


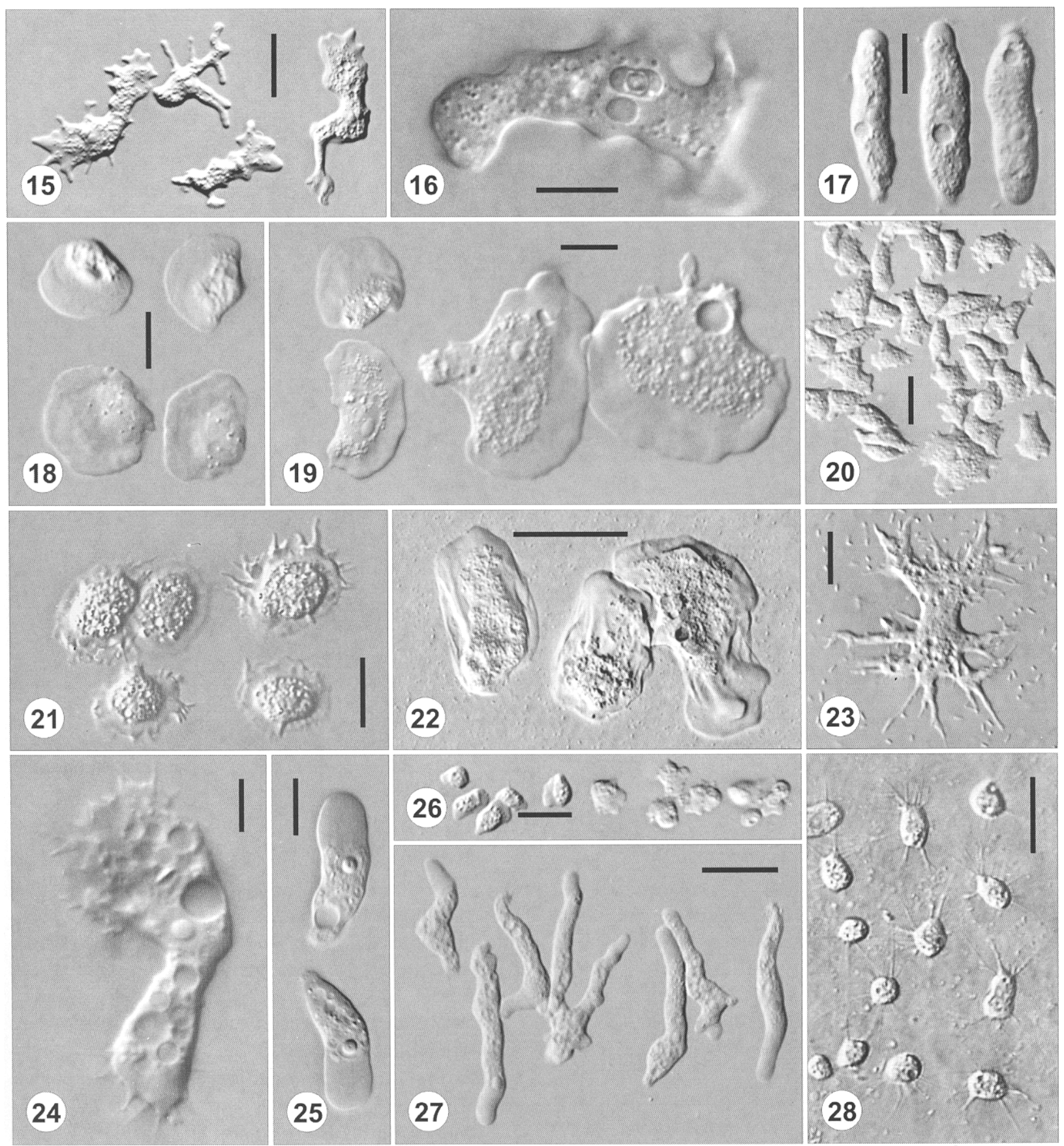

Figs. 15-28. Trophozoites of amphizoic amoebae isolated from organs of fish as seen in hanging drops, in Nomarski DIC. Fig. 15. Neoparamoeba sp. from gill tissue of Scophthalmus maximus. Fig. 16. Neoparamoeba sp. from gills of Dicentrarchus labrax. Fig. 17. Saccamoeba-like strain from gills of Atlantic salmon. Fig. 18. Representatives of two different Platyamoeba strains isolated from marine fish. Fig. 19. Representatives of two different Vannella strains, the smaller amoebae from gills of Scophthalmus maximus, the larger ones from gills of Hypophthalmichthys molitrix. Fig. 20. Trophozoites of Flabellula sp. Fig. 21. Cochliopodium sp. from gills of Perca fluviatilis. Fig. 22. Trophozoites of Thecamoeba sp. from S. maximus. Fig. 23. Trophozoite of Filamoeba sp. from gills of Carassius gibelio. Fig. 24. Trophozoite of Acanthamoeba sp. from kidney of Leuciscus cephalus. Fig. 25. Naegleria sp. from brain of Corydoras leucomelas. Fig. 26. Trophozoites tentatively assigned to Rosculus sp. Fig. 27. Hartmannella sp. from gills of Perca fluviatilis. Fig. 28. Nuclearia pattersoni from gills of Rutilus rutilus. Scale bars: Figs. 15, 20, 27, $28=20 \mu \mathrm{m}$; Figs. 16-19, 21, 23-26=10 $\mu \mathrm{m}$; Fig. $22=50 \mu \mathrm{m}$. 

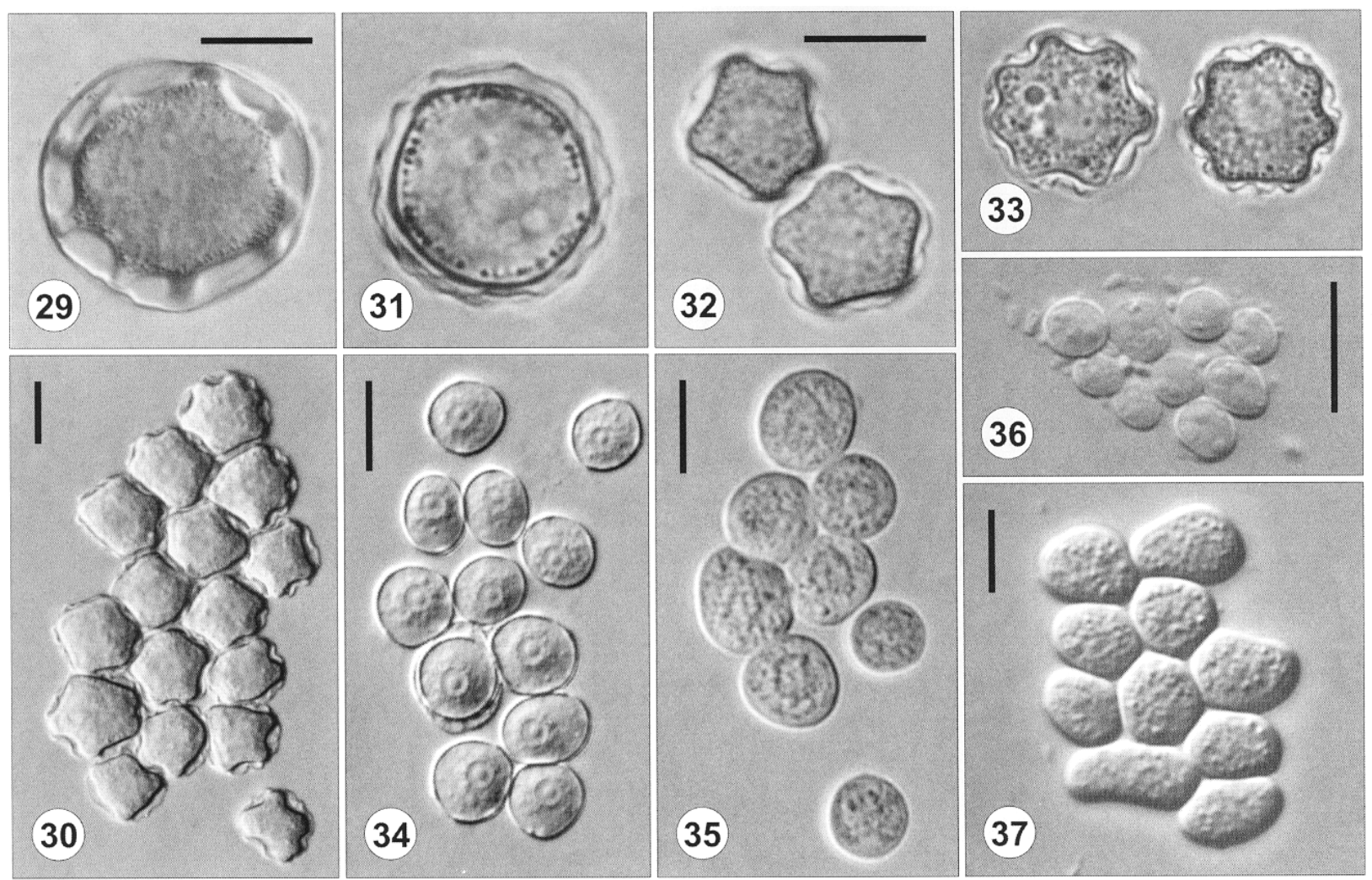

Figs. 29-37. Various types of cysts of amphizoic amoebae of fish origin. Fig. 29. Acanthamoeba astronyxis. Figs. 30-33. Acanthamoeba cysts belonging to the same morphotype (MG2) as observed in Nomarski DIC and in translucent light (Fig. 33). Fig. 34. Naegleria sp. Fig. 35. Hartmannella sp. Fig. 36. Rosculus sp. Fig. 37. Filamoeba sp. Scale bars: Figs. 29, 30, Fig. 32 (joint for Figs. 31, 33), Figs. 36-37=10 $\mu$; Figs. 34, $35=20 \mu \mathrm{m}$.

increased and criteria for orders and families changed several times. While in his monograph on marine gymnamoebae, Page (1983) still followed the system of 1976, in 1987 he published a modified classification of Rhizopoda and used it also in "A New Key to Freshwater and Soil Gymnamoebae" (Page 1988). This system included three classes of Gymnamoebia (Heterolobosea, Caryoblastea and Lobosea) and gymnamoebae incertae sedis. Another two classes of naked amoebae (Filosea and Granuloreticulosea) were included by the same author in his most recent monograph (Page 1991). Within the class Lobosea, Page recognised four orders of naked amoebae (Euamoebida, Leptomyxida, Acanthopodida and Loboreticulatida) and assigned them to the subclass Gymnamoebia.

Since phylogenetic analyses assessing relationships among taxa have been introduced and evolutionary importance of some features (e.g., types of mitochondrial cristae) recognised, amoebae, together with other groups of protists, changed their taxonomic status many times. Some classes were removed from Rhizopoda von Siebold, 1845 and some were elevated to phyla (CavalierSmith 1993, 1996/97, 1998). In his phylogenetic classification of Protozoa, Cavalier-Smith (2002) established two phyla of amoeboid organisms within the kingdom Protozoa: Amoebozoa with tubular cristae in mitochondria that include Lobosa and Conosa, and Percolozoa with discoid cristae that include Heterolobosea and Acrasida.

Some of the phylogenetic studies split up organisms formerly grouped together, while others confirmed relationships inferred already on the basis of morphological similarities (Sims et al. 1999, Amaral Zettler et al. 2000, 2001, Bolivar et al. 2001, Fahrni et al. 2003, Peglar et al. 2003).

Despite of intensive studies and important results already published, the intra-amoebozoan phylogeny based on SSU rRNA gene sequences (Amaral Zettler et al. 2000, 2001, Bolivar et al. 2001, Sims et al. 2002, Peglar et al. 2003) is still in its infancy. The agreement with morphology-based taxonomy is rather exceptional in taxa superior to genera and sometimes it is lacking even at the generic level (Sims et al. 2002). In general, molecular data give insights different from taxonomic schemes based on morphological characters. Nevertheless, it is important to accumulate them for the sake of future taxonomic synthesis of the group. 


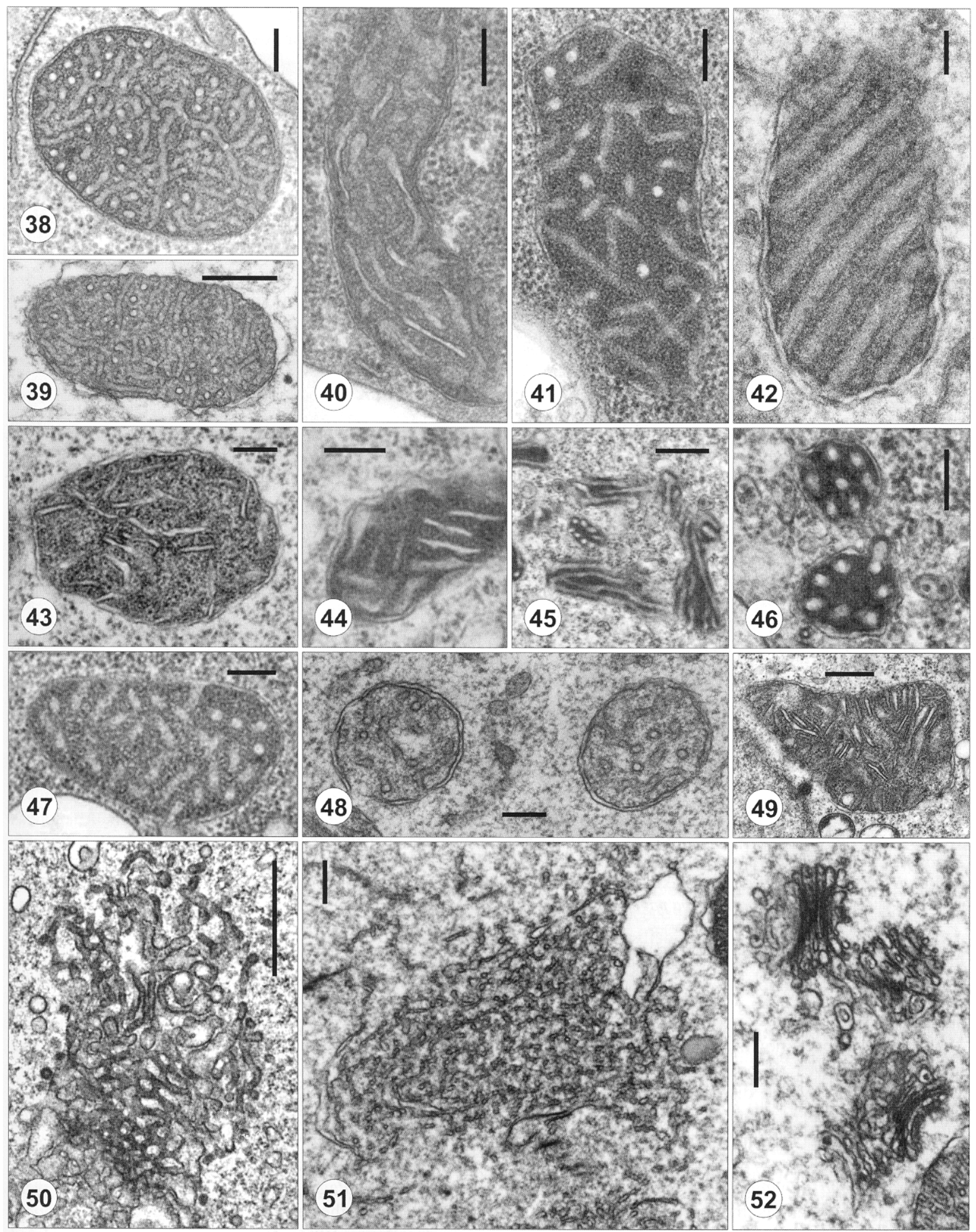

Figs. 38-52. Ultrastructural features of diagnostic importance in amphizoic amoebae. Figs. 38-49. Mitochondria with various types of cristae. Fig. 38. Tubular, branching cristae in Acanthamoeba sp. Fig. 39. Tubular, branching cristae in Thecamoeba sp. Fig. 40. Flattened cristae in Nuclearia sp. Fig. 41. Tubular cristae in Cochliopodium sp. Fig. 42. Straight tubular, paralelly arranged cristae in Saccamoeba-like species. Figs. 43, 44. Discoid cristae in Naegleria sp. Figs. 45, 46. Tubular, non-branching cristae in Filamoeba sp. Fig. 47. Tubular, branching cristae in Vannella sp. Fig. 48. Tubular cristae of relatively small mitochondria in Neoparamoeba sp. Fig. 49. Discoid cristae in Acrasida (Rosculus sp.). Fig. 50. Agranular endoplasmic reticulum in Neoparamoeba sp. Fig. 51. Plexiform network of smooth endoplasmic reticulum in trophozoite of Thecamoeba sp. Fig. 52. Three Golgi bodies in Thecamoeba sp. Scale bars: Figs. 38, $42=100$ nm; Figs. 40, 41, 43, 44, 46-48 = 200 nm; Figs. 39, 45, 49, $51,52=500 \mathrm{~nm}$; Fig. $50=1 \mu \mathrm{m}$. 


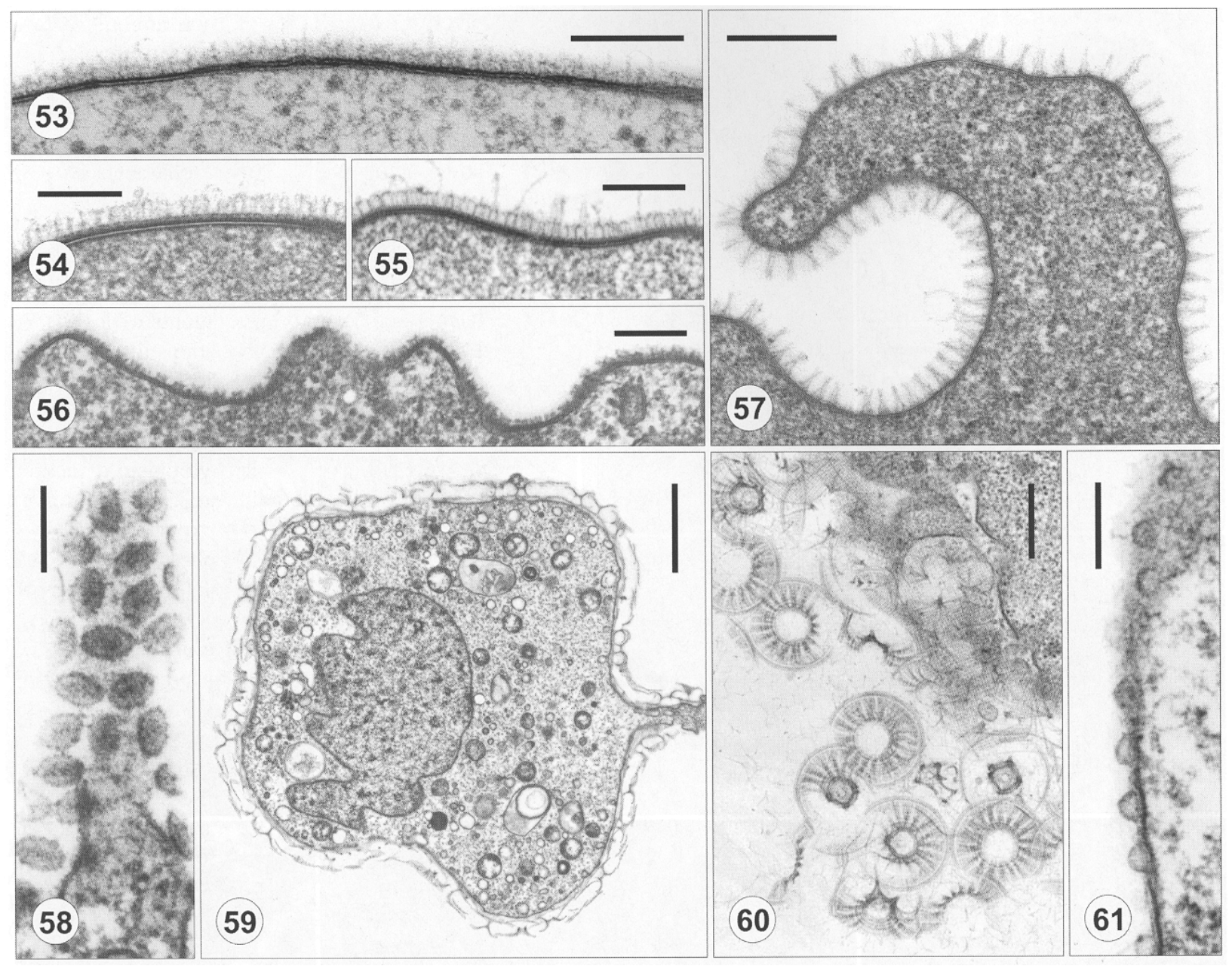

Figs. 53-61. Examples of glycocalyx differentiation in amphizoic amoebae isolated from fish organs. Fig. 53. Amorphous glycocalyx of Platyamoeba sp. Figs. 54, 55. Short glycostyles with intermingled long hairs (Platyamoeba spp.). Fig. 56. Glycostyles characteristic of Vexillifera spp. Fig. 57. Glycostyles of Vannella sp. Fig. 58. Scales on the surface of Corythionella sp. Figs. 59, 60. Microscales on the cell surface of Cochliopodium sp. (Fig. 60, view from above). Fig. 61. Glycocalyx structures on the cell surface of Pseudoparamoeba pagei. Scale bars: Figs. 53-56, 58, $61=200 \mathrm{~nm}$; Figs. 57, $60=500 \mathrm{~nm}$; Fig. $59=2 \mu \mathrm{m}$.

\section{AMPHIZOIC AMOEBAE - AGENTS OF FISH DISEASES}

\section{Gill-infecting species}

Among amoebae known to be able to colonise fish gills, representatives of only a few genera were described as agents of gill disease conditions. The most important outbreaks of amoebic gill disease resulting in mortalities were recorded in both freshwater and marine cultures of salmonids.

Neoparamoeba pemaquidensis (Page, 1970), which was studied in detail as the agent of gill disease in Atlantic salmon, Salmo salar, and turbot, Scophthalmus maximus (Kent et al. 1988b, Roubal et al. 1989, Dyková et al. 2000), represents an example of extraordinary pathogenic species of amphizoic amoeba (Fig. 62). Although amoebic gill disease (AGD) has emerged as one of the most severe health problems in the salmon fish industry (Munday et al. 1990, 1993, Rodger and McArdle 1996, Clark and Nowak 1999, Nowak et al. 2002), there was delay in determination of AGD agents from various localities. In the first conclusive report on the etiology of AGD, Kent et al. (1988b) determined the agent as Paramoeba pemaquidensis, most probably because they overlooked the classification of the Rhizopoda published by Page in 1987. In the latter article, Paramoeba Schaudinn, 1896 was reserved for species covered with microscales, while $P$. pemaquidensis and $P$. aestuarina Page, 1970, lacking such scales, were transferred to the newly established genus Neoparamoeba Page, 1987. Neoparamoeba strains isolated from gills of different hosts, Dicentrarchus labrax and Scophthalmus maximus (Dyková et al. 2000), and from localities distant to each other, were found to differ only in the size of trophozoites. Light and electron microscopy did not allow to distinguish species. Molecular 
characterisation of morphologically indistinguishable Neoparamoeba strains revealed the possibility that more than one species could cause AGD in turbot. In addition to $N$. pemaquidensis, the closely related $N$. aestuarina should be taken into consideration as well as a supposed third Neoparamoeba species (Fiala and Dyková 2003). The data accumulated on pathogenicity of the AGD agent in Atlantic salmon and on host-parasite relationships (Findlay et al. 1998, Clark and Nowak 1999, Zilberg et al. 1999, Douglas-Helders et al. 2000, 2001b, 2002, Zilberg and Munday 2000, Adams and Nowak 2001, Elliot et al. 2001) strongly influence the search for potential pathogens among other amoebae.

An undetermined amoeba of the family Cochliopodidae reported as an agent of the so-called nodular gill disease (NGD, see in Fig. 64) by Daoust and Ferguson (1985), Noble et al. (1994, 1997) and Speare (1999) and Thecamoeba hoffmani Sawyer, Hnath et Conrad, 1974 (Sawyer et al. 1974, 1975) were reported to be pathogenic for freshwater salmonids. Unfortunately, none of the records of amoebic gill disease attributed to amoebae of the family Cochliopodidae included an exact diagnosis of the agent. The same applies to Thecamoeba hoffmani.

Cochliopodium Hertwig et Lesser, 1874 spp. have been recorded from a broad range of habitats, both marine and freshwater (Bark 1973, Page 1988) but most of the species were described at the light microscopical level. Three species of this genus isolated either from activated sludge of a sewage treatment plant or from a small Sphagnum swamp were described in detail by Bark (1973). In addition, one strain of Cochliopodium isolated by Nagatani et al. (1981) from aquarium sediment was used by Yamaoka et al. (1984) for a scale formation study. Structural components of scales were examined also in C. bilimbosum (Auerbach, 1856) by Sadakane et al. (1996). The first correct identification of Cochliopodium sp. found to infect fish was that described by Dyková et al. (1998b) from an asymptomatic fish (see below).

Thecamoeba hoffmani was described mainly on the basis of trophozoite morphology as observed in tissue sections and, as the authors declared, also in wet mounts (Sawyer et al. 1974, 1975). Unfortunately, the morphology of trophozoites was documented in histological sections only. Despite incomplete description and documentation of $T$. hoffmani, the relationship between this agent and gill disease associated with mortalities in salmonid fingerlings exemplified the pathogenic potential of amoebae for freshwater and marine fish.

The taxonomic identity of amoebae associated with the etiology of proliferative gill disease (PGD) described by Hoffmann et al. (1992) in rainbow trout (Oncorhynchus mykiss) and those reported by Roger and Gaines (1975) in Tilapia aurea remained undetermined. Nash et al. (1988) described gill swelling associated with systemic infection caused by amoebae, which they tentatively assigned to the genus Acanthamoeba.

\section{Systemic infections of fish caused by amoebae}

The first systemic infection caused by amoebae in fish was reported by Taylor (1977). He successfully established systemic infections in experimental fishes using the Acanthamoeba strain of fish origin.

Spontaneous amoebic infections characterised by granulomatous organ lesions were described in goldfishes for the first time by Voelker et al. (1977). Similar infections were briefly described by Lom and Dyková (1992) and Steinhagen et al. (1993). Although amoebae were postulated to be the causative agents of lesions in the three publications mentioned, the ultrastructural study (Dyková et al. 1996) did not identify the agent as Rosculus ithacus Hawes, 1963, the only "true amoeba" that was isolated from infected goldfishes. Since no mitochondria were observed in the cytoplasm of agents of granulomatous lesions, the nature of these organisms remains open to speculations. In our experience, trophozoites that on the basis of their morphology can be assigned to Acrasida are frequently isolated together with other amphizoic amoebae.

Systemic infection caused by Naegleria australiensis De Jonckheere, 1981 was found in a hybrid of Clarias macrocephalus $\times$ gariepinus collected in a fish farm in Thailand (Dyková et al. 2001a).

There are also several reports on so-called X-cells. They were described in more than 20 species of fishes from different families, mainly pleuronectids and gadoids (Kent et al. 1988a). Those described from the liver of coho salmon, Oncorhynchus kisutch (Dyková et al. 1993) can possibly be related to multinucleated trophozoites of amoebae.

\section{AMPHIZOIC AMOEBAE ISOLATED FROM ORGANS OF ASYMPTOMATIC FISH}

To the best of our knowledge, we are the only research group involved in screening aimed at detection of free-living amoebae in organs of clinically healthy fish. Among marine fish species, attention was focused in particular to Scophthalmus maximus (Dyková et al. 1999b) and Salmo salar. In addition, individual representatives of four marine species belonging to three different families have been tested to date. The assemblage of freshwater fish examined comprises more than 30 species belonging to 12 families. In both freshwater and marine fish, the results of isolation attempts have exceeded expectations in the number of isolated strains and their diversity.

Flattened amoebae belonging to the family Vannellidae were the most numerous among strains isolated from tissues of marine fish. Representatives of the genera Vannella Bovee, 1965, Platyamoeba Page, 1969 and Flabellula Schaeffer, 1926 were isolated from the gills of asymptomatic as well as clinically diseased fish with AGD. In addition to the amoebae isolated and successfully cultured, two different species, Pseudoparamoeba cf. pagei and Corythionella sp. (Euglyphidae) were 
detected in material embedded for TEM from primary isolates growing on agar plates. Branched "buds" of Corallomyxa were rarely observed in seawater medium used for primary isolations. We have also isolated several Neoparamoeba strains from clinically healthy fish (Dyková et al. 1999b).

Thecamoeba $\mathrm{sp}$. isolated from gill tissue of turbot, Scophthalmus maximus, was tentatively, on the basis of trophozoite morphology, identified with $T$. hilla Schaeffer, 1926, which is one of the five marine species of this genus described thus far. This amoeba strain is mentioned below because trophozoites subcultured for more than two years contained an eukaryotic symbiont.

In freshwater fish, vannellids also belong to the most common amphizoic amoebae we have isolated from various organs. Ultrastructural features (types of glycocalyx) defined by Page (1980, 1983, 1988, 1991) allowed us to assign them to the genus Vannella Bovee, 1965 or Platyamoeba Page, 1969. Except for size differences, host origin and locality, no other features useful for species diagnosis or description of new species were observed in cultured trophozoites. The fact that the first sequence of SSU rRNA gene determined for Vannella species by Sims et al. (1999) has already been available inspired us to use the same marker gene and establish sequence variations within morphologically defined vannellid strains of fish origin. The initial purpose of this study limited to the search for molecular support of species delimitation within similar Vannella strains was then expanded to the search for genus-level boundaries. Simultaneously with our studies, Sims et al. (2002) found that Vannella and Platyamoeba spp. do not form separate clades in phylogenetic trees, but instead group together according to their habitat. Peglar et al. (2003) stressed that the degree to which cell surface structures are of taxonomic value can only be fully assessed when many more taxa within gymnamoebid lineages are studied. In accordance with their opinion we have decided to expand SSU rRNA gene data set with ultrastructurally defined strains of fish origin to determine reliability of the cell surface structures as diagnostic features (Dyková et al. in preparation).

Ten Acanthamoeba strains isolated from organs of asymptomatic freshwater feral fish were characterised morphologically and their ribosomal RNA gene sequences were compared with 53 other Acanthamoeba strains of different origin (Dyková et al. 1999a). Cyst morphology varied extensively within and among clones and gave no clear answer as to species identification. It is most likely morphological group II (MG2). Subgeneric classification was based on analyses of diagnostic fragments of $18 \mathrm{~S}$ rDNA sequences that are widely used in large Acanthamoeba data sets (Stothard et al. 1998). All fish strains (3 isolated from brain, 3 from liver, 2 from spleen and 2 from kidney) have the same type of sequences, thus belonging to T4 subset of MG2 that is closely related to strains commonly isolated from cases of human infections, especially of Acanthamoeba keratitis. Screening focused on gill-infecting amphizoic amoebae have revealed the presence of Acanthamoeba trophozoites on the gills of ornamental fish in most freshwater aquarium systems sampled to date.

Eighteen out of 40 Naegleria strains isolated from organs of five species of freshwater fishes (Blicca bjoerkna, Clarias hybrid, Oncorhynchus mykiss, Perca fluviatilis, Salvelinus fontinalis) have been studied in detail (Dyková et al. 2001a). Six strains, representatives of groups with slightly different size of cysts, were selected and corresponding clones derived from them were subjected to sequence- and riboprinting RFLPPCR analysis of the small subunit rRNA genes. One strain isolated from the brain of a fish with systemic infection was identified with Naegleria australiensis, the species originally described from flood drainage water in South Australia and later found to be pathogenic for homoiotherm host. Another five strains appeared in phylogenetic trees to be closely related to Naegleria clarki De Jonckheere, 1984. Surprisingly, none of the clones assayed by molecular methods grouped with $N$. gruberi, which was considered for a long time to be a widely distributed species. For comparison of a new assemblage of Naegleria strains isolated mostly from gills of feral fish, a set of 35 Naegleria spp. determined by De Jonckheere (2003) on the basis of their ITS rDNA sequences will be available.

Scale-bearing strains belonging to the genus Cochliopodium, another suspected pathogen of fish, were isolated from three different hosts, Perca fluviatilis, Gobio gobio and Silurus glanis. The strain isolated from gills and other organs of perch, Perca fluviatilis was identified with C. minus Page, 1976. Light microscopical generic assignment was confirmed by ultrastructural study of both the strain isolated from perch and environmental strain of C. minus (CCAP 1537/1A from the UK National Culture Collection) serving as a control (Dyková et al. 1998a). The morphology of another two strains isolated from the spleen of Gobio gobio and gills of Silurus glanis resembled that of $C$. minus.

Since Vexillifera bacillipedes Page, 1960 isolated from kidney of rainbow trout has been incorrectly designated as an agent of proliferative kidney disease (PKD) by Sawyer et al. (1978), only one more species of the genus has been recorded as amphizoic (Dyková et al. 1998b). The strain isolated from the liver of perch, Perca fluviatilis, could not be identified with any of the freshwater Vexillifera Schaeffer, 1926 species characterised by TEM and was therefore described as a new species $V$. expectata Dyková, Lom, Macháčková et Pecková, 1998. Hexagonal glycostyles discovered on the surface coat were similar to those of marine species of the genus.

A thus far unique representative of the genus Nuclearia Cienkowski, 1865 was isolated from the gills 

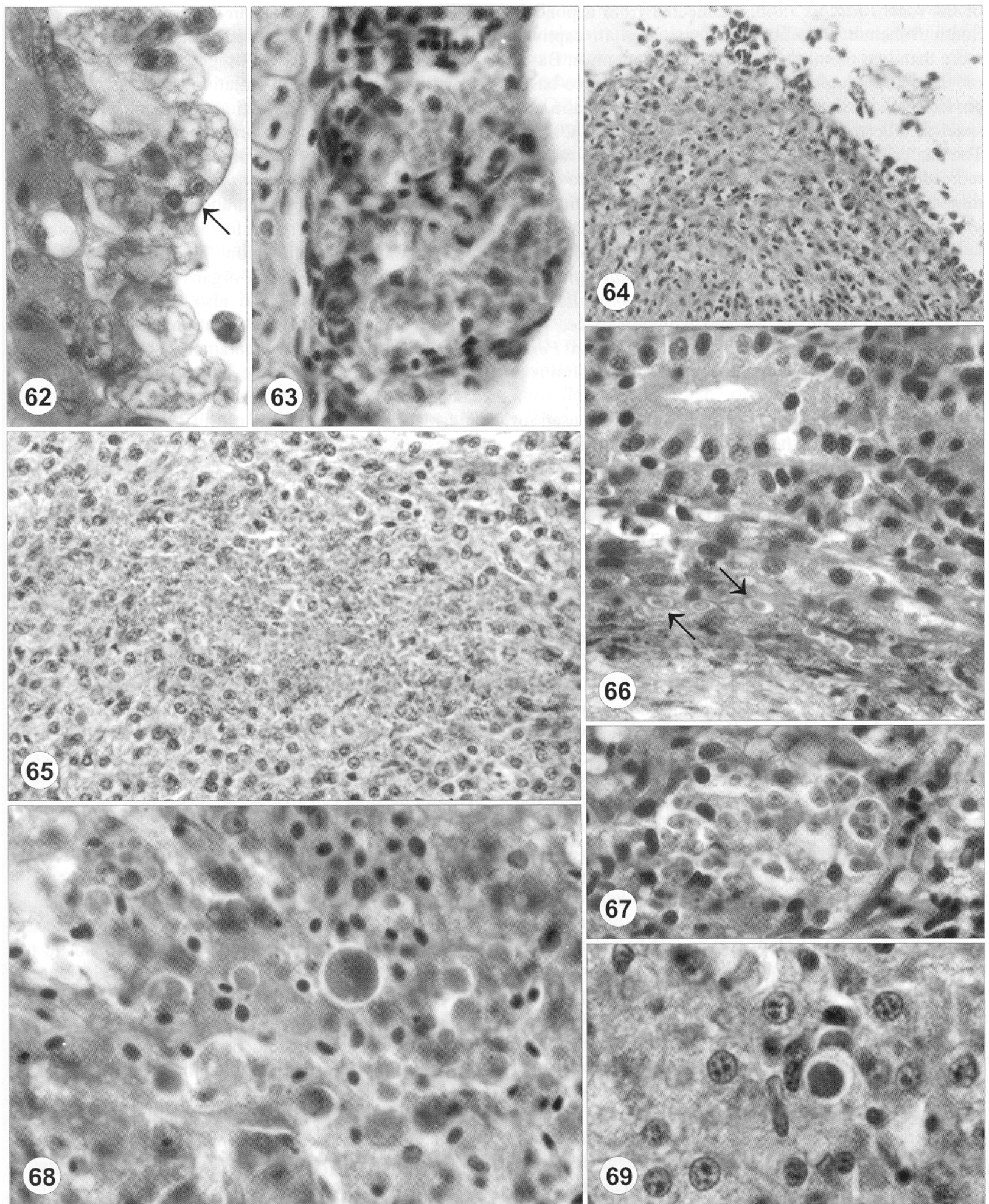

Figs. 62-69. Examples of true and suspected amoebic infections as seen in histological sections. Fig. 62. Amoebic gill disease in turbot, $\mathrm{H} \& \mathrm{E}, \times 950$. Trophozoites attached to gill tissue. Arrow indicates trophozoite with stained endosymbiont close to the nucleus. Fig. 63. Amoebic gill infection in Osteochilus hasselti, H\&E, $\times 870$. Fig. 64. Nodular gill disease, rainbow trout gills, H\&E, $\times 170$. Figs. 65-67. Granulomatous lesions in goldfishes due to infection with amoeba-like organisms. Periphery of the early (Fig. 65, H\&E, $\times 320$ ) and advanced granulomas (Fig. 66, H\&E, $\times 900$; Fig 67, H\&E, ×850). Arrows indicate causative agents. Figs. 68, 69. Suspected amoebic infections associated with necrotic changes in the liver of Perca fluviatilis (Fig. 68, H\&E, $\times 840$ ) and Cyprinus carpio (Fig. 69, H\&E, ×940). 
of the roach, Rutilus rutilus, collected from a pond in South Bohemia. The host fish was kept in captivity more than two months prior to isolation attempts. Based on the morphological description and sequence-based phylogenetic analyses, the strain was classified as a new species, Nuclearia pattersoni (Dyková et al. 2003b). The analysis of information available to date shows that more data on nucleariid amoebae are needed to determine their relationships within the genus and with other, insufficiently characterised species of similar genera.

Three strains isolated from internal organs of freshwater fish (from the liver of Tinca tinca, spleen of Cyprinus carpio and kidney of Oreochromis niloticus) were assigned to the genus Hartmannella Page, 1967 along with one strain isolated from the gills of Perca fluviatilis. Molecular characterisation of these strains is in progress.

The gills of Salmo salar fry, which has been used for salmon restocking of the river Elbe basin in the Czech Republic, were found infected with amoebae that were similar to Saccamoeba spp. when observed in the light microscope. High level of SSU rRNA gene sequence similarity with $S$. limax (strain F-13, ATCC 30942) was, however, at variance with results of comparative ultrastructural study. The strain from gills of $S$. salar differed from the previous and only ultrastructural description of S. limax (Page 1985), having regularly arranged, straight tubular, non-branching mitochondrial cristae (Dyková et al. 2002).

Strains of minute amoebae recognised on the basis of their morphology as belonging to Acrasida were frequently isolated together with other species of naked amoebae from organs of fish. They can also be considered potential fish pathogens. Many amoeba strains isolated from fish organs, e.g., those belonging to the genera Filamoeba Page, 1967, Echinamoeba Page, 1975 and Flabellula, are still in the process of identification as well as those in which morphological study was not sufficient for generic assignment.

\section{ETIOLOGICAL DIAGNOSIS OF AMOEBIC DISEASES AND SUSPECTED AMOEBIC LESIONS IN FISH}

Etiological diagnosis, which identifies the cause of lesions, is of primary importance in any disease problem. In general, eukaryotic microorganisms are not easy to determine in tissues. This applies in particular to trophic stages of amoebae, which lack rigid structures and are extremely changeable when subjected to different conditions. (Figs. 11-14).

The diagnostic methods developed during the research of AGD in Atlantic salmon were summarised by Zilberg et al. (1999), Douglas-Helders et al. (2001a), Elliot et al. (2001) and Nowak et al. (2002). Comments on diagnostic procedures and their pitfalls experienced during the research of AGD in turbot were published by Dyková and Novoa (2001).
In general, the key steps in the process of determination of amoebae as suspected agents of disease conditions include examination of gross lesions if present, sampling of tissues for isolation attempts, which are crucial for future identification of amoebae, and direct proof of pathogenicity of amoebae in histological sections. There are, however, limitations for each step of the procedure. Gross lesions are mostly non-specific. Nevertheless, squash preparations from macroscopic lesions can be indicative for isolation attempts and histopathological examination. The technique used for isolation of amoebae from organs of fish has already been mentioned above and also briefly described in Dyková et al. (1996). If the isolation attempt is successful, the primary isolate contains a homogeneous cell population, from which the strain and clonal cultures can easily be established. Less successful attempts result in isolation of a mixture of different amoebae. The process of separation of different cell populations is time-consuming. The suspected agent can be lost before adequate culturing conditions are prepared for it and/or because of rapid overgrowth of other simultaneously isolated species and bacteria. To identify isolated amoebae (i.e., clones derived from established strains), morphological and non-morphological methods have to be combined in most cases (see taxonomic criteria).

When fresh material is available and tissues can be sampled simultaneously for isolation attempts and histological examination, conclusive results on etiology of examined lesions can be expected. The etiology of most cases of suspected amoebic infections, observed incidentally in routinely examined histological material, remains obscure. Histological sections, irrespective of staining method, rise in most cases only suspicion of amoebic etiology of lesions (Figs. 63-69). Tentative etiology can be confirmed relatively easily only in the case of Neoparamoeba spp., agents of AGD. The symbiotic organism localised near the nucleus is a target detail that makes possible the identification of amoebae in sections (Fig. 62). In addition, rapid diagnostic test based on the immunofluorescent antibody technique (IFAT) has been developed (Elliot et al. 2001).

Since the ultimate goal in studies of pathogenicity of amphizoic amoebae would be to identify these organisms directly in histological sections, the development of specific diagnostic tools for individual genera and species is desirable.

\section{AMPHIZOIC AMOEBAE ISOLATED FROM FISH AS HOSTS OF OTHER ORGANISMS}

In all their habitats, free-living amoebae are exposed to other organisms. They are able to ingest and feed on many of them. Bacteria as well as other prokaryotes are able to infect amoebae, proliferate inside their cells and kill them or establish symbiotic associations (Daniels et al. 1966, Lee et al. 1985, Bradley and Marciano-Cabral 1996). Only a few studies have been devoted to symbi- 
otic associations of amoebae with algae (Lee et al. 1985, Karpov et al. 1991). The other protistan endobionts of amoebae have been neglected as is apparent from the lack of data in a review on amoebae, flagellates and ciliates as host organisms of various symbionts (Ossipov et al. 1997).

Bacteria that share the same habitats with amphizoic amoebae infecting fish are transferred with primary isolates of amoebae to agar plate cultures. When localised in food vacuoles or surrounded by amoeba cell membrane with differentiated glycocalyx, there is no doubt that bacteria have recently been phagocytosed. An accidental proliferation of bacteria in the cytoplasm of amoebae is not always easy to distinguish from an established symbiotic association of both organisms.

Transmission electron microscopy routinely employed in the research of generic and species composition of amoebae infecting freshwater and marine fish have expanded the knowledge of organisms living in the cytoplasm of amoebae.

After a long period of axenisation, Acanthamoeba trophozoites of strains isolated from the liver of Perca fluviatilis and brain of Leuciscus cephalus continued to host bacteria in their cytoplasm. Trophozoites of the Acanthamoeba strain isolated from the spleen of Silurus glanis contained virus-like particles. In addition to the frequent occurrence of facultative endosymbionts, stable symbiotic relationships have also been recognised between amphizoic amoebae of fish origin and bacteria.

The cytoplasm of a newly described species of amphizoic amoeba, Nuclearia pattersoni isolated from the gills of Rutilus rutilus, contained rod-shaped bacteria, which on the basis of phylogenetic analyses were classified as Rickettsia sp. related to endosymbionts of leeches (Dyková et al. 2003b). Trophozoites of $N$. pattersoni harboured rickettsial cells over a long period of subculturing (two years after primary isolation).

In amphizoic amoebae isolated from organs of marine fish, in addition to prokaryotes, also eukaryotes have been recognised as endosymbiotic partners. A species of the genus Labyrinthula Cienkowski, 1867 (Myxomycota) was found in the cytoplasm of Thecamoeba hilla Schaeffer, 1926 isolated from gills of Scophthalmus maximus. Neither effort to clear the amoebae of this organism, nor cloning procedure could eliminate it from the amoebae. The co-existence of both organisms sustainable for more than two years (no sign of destruction of Labyrinthula cells in the cytoplasm of amoebae was observed) could also be interpreted as stable type of symbiotic association.

The symbiotic organisms resembling Perkinsiella amoebae Hollande, 1980 described previously in Janickina spp. from chaetognaths, were found in trophozoites of all Neoparamoeba strains isolated from turbot and salmon (Dyková et al. 1998c, 2003a). Similar organisms were recorded from seven species belonging to three genera of the family Paramoebidae. Comparative study of these organisms in trophozoites of six Neoparamoeba strains isolated from gills of turbot, Scophthalmus maximus revealed their mutual similarity. The morphology of Perkinsiella amoebae-like organisms (PLOs) supported Hollande's hypothesis (Hollande 1980) about their kinetoplastid origin. The first conclusive results on this hypothesis were obtained in a study by Dyková et al. (2003a) using two marker genes. The recognition of euglenozoan spliced leader RNA (SL RNA) gene sequences in the genomic DNA of endosymbionts from five Neoparamoeba strains, together with the acquisition of one SSU RNA gene sequence, allowed us to specify the relationship of the endosymbionts with kinetoplastids. Phylogenetic analyses of SSU rRNA gene sequence data currently available revealed close relationship of the first sequenced Perkinsiella amoebae-like organism with Ichthyobodo necator. Three types of the SL RNA gene sequences obtained from PLOs were congruent with phylogeny of their Neoparamoeba host strains.

\section{PROSPECTS OF FUTURE RESEARCH}

Research of amphizoic amoebae of fish is still at its beginning in spite of results briefly mentioned above. This statement applies to both the benefits their study may offer to fish pathology and husbandry and to accumulation of important data for fundamental knowledge.

Determination of the prevalence of amphizoic amoebae in fish and definition of their potential to inflict disease conditions upon their hosts is of basic interest for fish parasitology. A prerequisite to progress in this direction is the further development of convenient methods of diagnostics and generic and species determination of amoebic agents. It is obvious that morphological characteristics alone are not sufficient to characterise and identify all important taxa and morphological differences may be misleading in classifying amoebae. The investigation into interspecific and intraspecific diversity of selected taxons may help to uncover alternative biological approaches for disease control of some important pathogens, such as Neoparamoeba spp.

The number of free-living and amphizoic amoebae that have been characterised by both morphological and molecular methods makes up only a small fraction of the species described thus far. This also applies to amoeba strains of fish origin. Further progress is necessary on both fronts. Detection of signature sequences in newly described species could greatly facilitate future identification and comparisons. Research on marker genes should be aimed at specific diagnostic tools for individual genera and species of amoebae, which should be followed by construction of diagnostic primers suitable for in situ hybridisation in histological sections. The identification of amphizoic amoebae in histological material can significantly contribute to revealing their pathogenicity. 
New data on symbiotic associations established between amoebae and other organisms open an intriguing vista for future researchers. The presence of viable pathogenic bacteria inside free-living amoebae offers a new challenge for studies on interrelations between parasitic organisms. The role of amoebae as vectors of human pathogens, e.g., Legionella, has been well studied. An untouched field is, however, the significance of amphizoic amoebae for transmission and dispersion of specific fish pathogens.
One can expect that the challenge presented by all these problems will attract attention and result in rapid development of this field of fish parasitology.

Acknowledgements. This study was supported by the Grant Agency of the Academy of Sciences of the Czech Republic (Projects nos. A6022202 and Z6022909) and by the Ministry of Education, Youth and Sports of the Czech Republic (Project MSM 1231-00003).

\section{REFERENCES}

ADAMS M., NOWAK B.F. 2001: Distribution and structure of lesions in the gills of Atlantic salmon (Salmo salar L.) affected with amoebic gill disease. J. Fish Dis. 24: 535542.

AMARAL ZETTLER L.A., NERAD T.A., O'KELLY C.J., PEGLAR M.T., GILLEVET P.M., SILBERMAN J.D., SOGIN M.L. 2000: A molecular reassessment of the leptomyxid amoebae. Protist 151: 275-282.

AMARAL ZETTLER L.A., NERAD T., O'KELLY C.J., SOGIN M.L. 2001: The nucleariid amoebae: more protists at the animal-fungal boundary. J. Eukaryot. Microbiol. 48: 293-297.

BARK A.W. 1973: A study of the genus Cochliopodium Hertwig and Lesser, 1874. Protistologica 9: 119-138.

BOLIVAR I., FAHRNI J.F., SMIRNOV A., PAWLOWSKI J. 2001: SSU rRNA-based phylogenetic position of the genera Amoeba and Chaos (Lobosea, Gymnamoebia): the origin of Gymnamoebae revisited. Mol. Biol. Evol. 18: 2306-2314.

BRADLEY S.G., MARCIANO-CABRAL F. 1996: Diversity of free-living naked amoeboid organisms. J. Ind. Microbiol. 17: 314-321.

CAVALIER-SMITH T. 1993: Kingdom Protozoa and its 18 phyla. Microbiol. Rev. 57: 953-994.

CAVALIER-SMITH T. 1996/97: Amoeboflagellates and mitochondrial cristae in eukaryote evolution: megasystematics of the new protozoan subkingdoms Eozoa and Neozoa. Arch. Protistenkd. 147: 237-258.

CAVALIER-SMITH T. 1998: A revised six-kingdom system of life. Biol. Rev. 73: 203-266.

CAVALIER-SMITH T. 2002: The phagotrophic origin of eukaryotes and phylogenetic classification of Protozoa. Int. J. Syst. Evol. Microbiol. 52: 297-354.

CLARK A., NOWAK B.F. 1999: Field investigations of amoebic gill disease in Atlantic salmon, Salmo salar L., in Tasmania. J. Fish Dis. 22: 433-443.

DANIELS E.W., BREYER E.P., KUDO R.R. 1966: Pelomyxa palustris Greef. II. Its ultrastructure. Z. Zellforsch. 73: 367-383.

DAOUST P.Y., FERGUSON H.W. 1985: Nodular gill disease in rainbow trout, Salmo gairdneri Richardson. J. Fish Dis. 8: 511-522.

De JONCKHEERE J.F. 1983: Isoenzyme and total protein analysis by agarose isoelectric focusing and taxonomy of the genus Acanthamoeba. J. Protozool. 30: 701-706.
De JONCKHEERE J.F. 1988: Geographic origin and spread of pathogenic Naegleria fowleri deduced from restriction enzyme patterns of repeated DNA. BioSystems 21: 269275.

De JONKHEERE J.F. 2002: A century of research on the amoeboflagellate genus Naegleria. Acta Protozool. 41: 309-342.

De JONCKHEERE J.F. 2003: Studies on the systematics, phylogeny and pathogenicity of Naegleria using ribosomal DNA sequences. Proceedings of the Xth International Meeting on the Biology and Pathogenicity of Free-living Amoebae. October 5-10 2003, Cd. Obregón, Sonora, Mexico, ITSON-DIEP, pp. 73-81.

DOUGLAS-HELDERS M.G., CARSON J., HOWARD T., NOWAK B. 2001a: Development and validation of a new dot blot test for the detection of Paramoeba pemaquidensis (Page) in fish. J. Fish Dis. 24: 273-280.

DOUGLAS-HELDERS M.G., SAKSIDA S., RAVERTY S., NOWAK B. 2001b: Temperature as a risk factor for outbreaks of Amoebic Gill Disease in farmed Atlantic salmon (Salmo salar). Bull. Eur. Assoc. Fish Pathol. 21: 114-116.

DOUGLAS-HELDERS M.G., DAWSON D.R., CARSON J., NOWAK B.F. (2002): Wild fish are not a significant reservoir of Neoparamoeba pemaquidensis. J. Fish Dis. 25: 569-574.

DOUGLAS-HELDERS M.G., NOWAK B., ZILBERG D., CARSON J. 2000: Survival of Paramoeba pemaquidensis on dead salmon: implications for management of cage hygiene. Bull. Eur. Assoc. Fish Pathol. 20: 167-169.

DYKOVÁ I., FIALA I., LOM J., LUKEŠ J. 2003a: Perkinsiella amoebae-like endosymbionts of Neoparamoeba spp., relatives of the kinetoplastid Ichthyobodo. Eur. J. Protistol. 39: 53-61.

DYKOVÁ I., FIGUERAS A., NOVOA B. 1993: X-cell lesions in the liver of coho salmon Oncorhynchus kisutch. Dis. Aquat. Org. 15: 171-174.

DYKOVÁ I., FIGUERAS A., NOVOA B. 1999b: Epizoic amoebae from the gills of turbot Scophthalmus maximus. Dis. Aquat. Org. 38: 33-38.

DYKOVÁ I., FIGUERAS A., NOVOA B., FERNANDEZ CASAL J. 1998c: Paramoeba sp., an agent of amoebic gill disease of turbot Scophthalmus maximus. Dis. Aquat. Org. 33: 137-141.

DYKOVÁ I., FIGUERAS A., PERIC Z. 2000: Neoparamoeba Page, 1987: light and electron microscopic observations 
on six strains of different origin. Dis. Aquat. Org. 43: 217223.

DYKOVÁ I., KYSELOVÁ I., PECKOVÁ H., OBORNÍK M., LUKEŠ J. 2001: Identity of Naegleria strains isolated from organs of freshwater fishes. Dis. Aquat. Org. 46: $115-121$.

DYKOVÁ I., LOM J., MACHÁČKOVÁ B. 1998a: Cochliopodium minus, a scale-bearing amoeba isolated from organs of perch Perca fluviatilis. Dis. Aquat. Org. 34: 205-210.

DYKOVÁ I., LOM J., MACHÁČKOVÁ B., SAWYER T.K. 1996: Amoebic infections in goldfishes and granulomatous lesions. Folia Parasitol. 43: 81-90.

DYKOVÁ I., LOM J., SCHROEDER-DIEDRICH J.M., BOOTON G.C., BYERS T.J. 1999a: Acanthamoeba strains isolated from organs of freshwater fishes. J. Parasitol. 85: 1106-1113.

DYKOVÁ I., MACHÁČKOVÁ B., PECKOVÁ H. 1997: Amoebae isolated from organs of farmed tilapias, Oreochromis niloticus. Folia Parasitol. 44: 81-90.

DYKOVÁ I., MACHÁČKOVÁ B., PECKOVÁ H. 1998b: Vexillifera expectata sp. $\mathrm{n}$. and other non-encysting amoebae isolated from organs of freshwater fish. Folia Parasitol. 45: 17-26.

DYKOVÁ I., NOVOA B. 2001: Comments on diagnosis of amoebic gill disease (AGD) in turbot, Scophthalmus maximus. Bull. Eur. Assoc. Fish Pathol. 21: 40-44.

DYKOVÁ I., VEVERKOVÁ M., FIALA I., MACHÁČKOVÁ B. 2002: A free-living amoeba with unusual pattern of mitochondrial structure isolated from Atlantic salmon, Salmo salar L. Acta Protozool. 41: 415-419.

DYKOVÁ I., VEVERKOVÁ M., FIALA I., MACHÁČKOVÁ B., PECKOVÁ H. 2003b: Nuclearia pattersoni sp. n. (Filosea), a new species of amphizoic amoeba isolated from gills of roach (Rutilus rutilus), and its rickettsial endosymbiont. Folia Parasitol. 50: 161-170.

ELLIOT N.G., WONG F., CARSON J. 2001: Detection and abundance of Paramoeba species in the environment. CSIRO Marine Research, Hobart, $68 \mathrm{pp}$.

FAHRNI J.F., BOLIVAR I., BERNEY C., NASSONOVA E., SMIRNOV A., PAWLOWSKI J. 2003: Phylogeny of lobose amoebae based on actin and small-subunit ribosomal RNA genes. Mol. Biol. Evol. 20: 1881-1886.

FIALA I., DYKOVÁ I. 2003: Molecular characterisation of Neoparamoeba strains isolated from gills of Scophthalmus maximus. Dis. Aquat. Org. 55: 11-16.

FINDLAY V.L., MUNDAY B.L. 1998: Further studies on acquired resistance to amoebic gill disease (AGD) in Atlantic salmon, Salmo salar L. J. Fish Dis. 21: 121-125.

GAST R.J., LEDEE D.R., FUERST P.A., BYERS T.J. 1996: Subgenus systematics of Acanthamoeba: four nuclear $18 \mathrm{~S}$ rDNA sequence types. J. Eukaryot. Microbiol. 43: 498504.

HOFFMANN R.W., El-MATBOULI M., FISCHER-SCHERL T. 1992: A proliferative gill disease (PGD) in rainbow trout (Oncorhynchus mykiss). Bull. Eur. Assoc. Fish Pathol. 12: 139-140.

HOLLANDE A. 1980: Identification du parasome (Nebenkern) de Janickina pigmentifera a un symbionte (Perkin- siella amoebae nov. gen. - nov. sp.) apparenté aux flagellés Kinetoplastidiés. Protistologica 16: 613-625.

HONIGBERG B.M., BALAMUTH W., BOVEE E.C., CORLISS J.O., GOJDICS M., HALL R.P., KUDO R.R., LEVINE N.D., LOEBLICH A.R. Jr., WEISER J., WENRICH D.H. 1964: A revised classification of the phylum Protozoa. J. Protozool. 11: 7-20.

HOPWOOD D., MILNE G. 1991: Fixation. In: J.R. Harris (Ed.), Electron Microscopy in Biology. A Practical Approach. The Practical Approach Series. Oxford University Press, New York, pp. 8-9.

JOHN D.T. 1993: Opportunistically pathogenic free-living amoebae. In: J.P. Kreier and J.R. Baker (Eds.), Parasitic Protozoa. Volume 3. Academic Press, San Diego, pp. 143-246.

KALININA L.V., PAGE F.C. 1992: Culture and preservation of naked amoebae. Acta Protozool. 31: 115-126.

KARPOV A.S., GOODKOV A.V., MARINICH M.A. 1991: The variety of algae-bearing invertebrates from inner lakes of the Valamo Island. Zool. Zh. 70 (6): 5-10. (In Russian.)

KENT M.L., MYERS M.S., WELLINGS S.R., ELSTON R.A. 1988a: An internal X-cell pseudotumor in a black croaker (Cheilootrema saturnum). J. Wildl. Dis. 24: 142-145.

KENT M.L., SAWYER T.K., HEDRICK R.P. 1988b: Paramoeba pemaquidensis (Sarcomastigophora, Paramoebidae) infestation of the gills of coho salmon Oncorhynchus kisutch reared in sea water. Dis. Aquat. Org. 5: 163-169.

LEE J.J., SOLDO A.T., REISSER W., LEE M.J., JEON K.W., GÖRTZ H.D. 1985: The extent of algal and bacterial endosymbioses in Protozoa. J. Protozool. 32: 391-403.

LEVINE N.D., CORLISS J.O., COX F.E.G., DEROUX G., GRAIN J., HONIGBERG B.M., LEEDALE G.F., LOEBLICH A.R., LOM J., LYNN D., MERINFELD E.G., PAGE F.C., POLJANSKY G., SPRAGUE V., VÁVRA J., WALLACE F.G. 1980: A newly revised classification of the Protozoa. J. Protozool. 27: 37-58.

LOM J., DYKOVÁ I. 1992: Protozoan Parasites of Fishes. Developments in Aquaculture and Fisheries Science 26. Elsevier Science Publishers, Amsterdam, 315 pp.

MARTINEZ A.J. 1985: Free-living Amoebas. CRC Press, Boca Raton, Florida, 156 pp.

MARTINEZ A.J., VISVESVARA G.S. 1997: Free-living, amphizoic and opportunistic amoebas. Brain Pathol. 7: 583-598.

MEDLIN L., ELWOOD H.J., STICKEL S. 1998: The characterization of enzymatically amplified eukaryotic 16S-like rRNA-coding regions. Gene 71: 491-499.

MUNDAY B.L., FOSTER C.K., ROUBAL F.R., LESTER R.J.G. 1990: Paramoebic gill infection and associated pathology of Atlantic salmon, Salmo salar, and rainbow trout, Salmo gairdneri in Tasmania. In: F.O. Perkins and T.C. Cheng (Eds.), Pathology in Marine Science. Academic Press, London, UK, pp. 215-222.

MUNDAY B.L., LANGE K., FOSTER C., LESTER R.J.G., HANDLINGER J. 1993: Amoebic gill disease of seacaged salmonids in Tasmania waters. Tasmanian Fish. Res. 28: 14-19.

NAGATANI Z., YAMAOKA I., SATO N. 1981: Scale structure of the external surface of an amoeba. Zool. Mag. (Tokyo) 90: 112-115. 
NASH G., NASH M., SCHLOTFELD H.J. 1988: Systemic amoebiasis in cultured European catfish, Silurus glanis L. J. Fish Dis. 11: 57-71.

NOBLE A., HERMAN R., NOGA E., BULLOCK G. 1994: Description of a recurrent amoeba gill infestation in rainbow trout (Oncorhynchus mykiss) cultured in a semiclosed recirculating system. Int. Symp. Aquat. Anim. Health, Seattle, Washington, September 4-8, 1994. Abstract W10.1 .

NOBLE A.C., HERMAN R.L., NOGA E.J., BULLOCK G.L. 1997: Recurrent amoebic gill infestation in rainbow trout cultured in a semiclosed water recirculation system. J. Aquat. Anim. Health 9: 64-69.

NOWAK B., CARSON J., POWELL M.D., DYKOVÁ I. 2002: Amoebic Gill Disease in the marine environment Bull. Eur. Assoc. Fish Pathol. 22: 144-147.

OSSIPOV D.V., KARPOV S.A., SMIRNOV A.V., RAUTIAN M.S. 1997: Peculiarities of the symbiotic systems of protists with diverse patterns of cellular organisation. Acta Protozool. 36: 3-21.

PAGE F.C. 1974: Rosculus ithacus Hawes, 1963, Amoebida, Flabellulidea and the amphizoic tendency in amoebae. Acta Protozool. 13: 143-154.

PAGE F.C. 1976: A revised classification of the Gymnamoebia (Protozoa: Sarcodina). Zool. J. Linn. Soc. 58: 61-77.

PAGE F.C. 1980: A light- and electron-microscopical comparison of limax and flabellate marine amoebae belonging to four genera. Protistologica 16: 57-78.

PAGE F.C. 1983: Marine Gymnamoebae. Institute of Terrestrial Ecology, Culture Centre of Algae and Protozoa Cambridge, England, 54 pp.

PAGE F.C. 1985: The limax amoebae: comparative fine structure of the Hartmannellidae (Lobosea) and further comparisons with the Vahlkampfiidae (Heterolobosea). Protistologica 21: 361-383.

PAGE F.C. 1987: The classification of "naked" amoebae of phylum Rhizopoda. Arch. Protistenkd. 133: 199-217.

PAGE F.C. 1988: A New Key to Freshwater and Soil Gymnamoebae. Freshwater Biological Association, Ambleside, Cumbria, 122 pp.

PAGE F.C. 1991: Nackte Rhizopoda In: F.C. Page and F.J. Siemensma: Nackte Rhizopoda und Heliozoea. Protozoenfauna Band 2. Gustav Fischer Verlag, Stuttgart, New York, pp. 8-170.

PEGLAR M.T., AMARAL ZETTLER L.A., ANDERSON O.R., NERAD T.A., GILLEVET P.M., MULLEN T.E., FRASCA S. Jr., SILBERMAN J.D., O'KELLY C.J., SOGIN M.L. 2003: Two new small-subunit ribosomal RNA gene lineages within the subclass Gymnamoebida. J. Eukaryot. Microbiol. 50: 224-232.

PERNIN P., CARIOU M.L., JACQUIER A. 1985: Biochemical identification and phylogenetic relationships in freeliving amoebas of the genus Naegleria. J. Protozool. 32: 592-603.

RODGER H.D., McARDLE J.F. 1996: An outbreak of amoebic gill disease in Ireland. Vet. Rec. 139: 348-349.

ROGER W.A., GAINES J.L. Jr. 1975: Lesions of protozoan diseases in fish. In: W.E. Ribelin and G. Migaki (Eds.), The Pathology of Fishes. University of Wisconsin Press, Madison, Wisconsin, pp. 117-141.
ROUBAL F.R., LESTER R.J.G., FOSTER C.K. 1989: Studies on cultured and gill-attached Paramoeba sp. (Gymnamoebae: Paramoebidae) and the cytopathology of paramoebic gill disease in Atlantic salmon, Salmo salar L., from Tasmania. J. Fish Dis. 12: 481-493.

SADAKANE K., MURAKAMI R., YAMAOKA I. 1996: Cytochemical and ultrastructural studies of the scales of the amoeba Cochliopodium bilimbosum (Testacea). Eur. J. Protistol. 32: 311-315.

SAWYER T.K., GHITTINO P., ANDRUETTO S., PERNIN P., PUSSARD M. 1978: Vexillifera bacillipedes Page, 1969, an amphizoic amoeba of hatchery rainbow trout in Italy. Trans. Am. Microsc. Soc. 97: 596-600.

SAWYER T.K., HNATH J.G., CONRAD J.F. 1974: Thecamoeba hoffmani sp. n. (Amoebida: Thecamoebidae) from gills of fingerling salmonid fish. J. Parasitol. 60: 677-682.

SAWYER T.K., HOFFMAN G.L., HNATH J.G., CONRAD J.F. 1975: Infection of salmonid fish gills by aquatic amoebas (Amoebida: Thecamoebidae). In: W.E. Ribelin and G. Migaki (Eds.), The Pathology of Fishes. University of Wisconsin Press, Madison, Wisconsin, pp. 143-150.

SCHROEDER J.M., BOOTON G.C., HAY J., NISZL I.A., SEAL D.V., MARKUS M.B., FUERST P.A., BYERS T.J. 2001: Use of subgenic 18S ribosomal DNA PCR and sequencing for genus and genotype identification of acanthamoebae from humans with keratitis and from sewage sludge. J. Clin. Microbiol. 39: 1903-1911.

SIMS G.P., AITKEN R., ROGERSON A. 2002: Identification and phylogenetic analysis of morphologically similar naked amoebae using small subunit ribosomal RNA. J. Eukaryot. Microbiol. 49: 478-484.

SIMS G.P., ROGERSON A., AITKEN R. 1999: Primary and secondary structure of the small-subunit ribosomal RNA of the naked, marine amoeba Vannella anglica: phylogenetic implications. J. Mol. Evol. 48: 740-749.

SINGH B.N. 1952: Nuclear division in nine species of small free-living amoebae and its bearing on the classification of the order Amoebida. Philos. Trans. R. Soc. Lond., Ser. B, 236: 405.

SMIRNOV A.V., GOODKOV A.V. 1999: An illustrated list of basic morphotypes of Gymnamoebia (Rhizopoda, Lobosea). Protistology 1: 20-29.

SOGIN M.L. 1990: Amplification of ribosomal RNA genes for molecular evolution studies. In: M.A. Iunis, D.H. Gelfand, J.J. Sninsky and T.J. White (Eds.), PCR Protocols: A Guide to Methods and Applications. Academic Press, San Diego, California, pp. 307-314.

SOGIN M.L., SILBERMAN J.D. 1998: Evolution of the protists and protistan parasites from the perspective of molecular systematics. Int. J. Parasitol. 28: 11-20.

SPEARE D.J. 1999: Nodular gill disease (amoebic gill infestation) in char, Salvelinus alpinus. J. Comp. Pathol. 121: 277-282.

STEINHAGEN D., JENDRYSEK S., KÖRTING W. 1993: Amöbiasis bei Goldfischen. Kleintierpraxis 38: 469-474.

STOTHARD D.R., SCHROEDER-DIEDRICH J.M., AWWAD M.H., GAST R.J., LEDEE D.R., RODRIGUEZZARAGOZA S., DEAN C.L., FUERST P.A., BYERS T.J. 1998: The evolutionary history of the genus Acanth- 
amoeba and the identification of eight new 18S rRNA gene sequence types. J. Eukaryot. Microbiol 45: 45-54.

TAYLOR P.W. 1977: Isolation and experimental infection of free-living amoebae in freshwater fishes. J. Parasitol. 63: 232-237.

VEVERKOVÁ M., DYKOVÁ I., PECKOVÁ H. 2002: Experimental study on pathogenic potential of six Acanthamoeba strains isolated from fish. Folia Parasitol. 49: 243-245.

VISVESVARA G.S., SCHUSTER F.L., MARTINEZ A.J. 1993: Balamuthia mandrillaris, n. g., n. sp., agent of amoebic meningoencephalitis in humans and animals. J. Eukaryot. Microbiol. 40: 504-515.

VISVESVARA G.S., STEHR-GREEN J.K. 1990: Epidemiology of free-living amoeba infections. J. Protozool. 37: $25 \mathrm{~S}-33 \mathrm{~S}$.

Received 29 January 2004
VOELKER F.A., ANVER M.R., McKEE A.V., CASEY H.W., BRENNIMAN G.R. 1977: Amebiasis in goldfish. Vet. Pathol. 14: 247-255.

WEEKERS P.H.H., De JONCKHEERE J.F. 1997: Differences in isoenzyme patterns of axenically and monoxenically grown Acanthamoeba and Hartmannella. Antonie van Leeuwenhoek 71: 231-237.

YAMAOKA I., KAWAMURA N., MIZUNO M., NAGATANI Y. 1984: Scale formation in an amoeba Cochliopodium sp. J. Protozool. 31: 267-272.

ZILBERG D., MUNDAY B.L. 2000: Pathology of experimental gill disease in Atlantic salmon, Salmo salar L., and the effect of pre-maintenance of fish in sea water on the infection. J. Fish Dis. 23: 401-407.

ZILBERG D., NOWAK B., CARSON J., WAGNER T. 1999: Simple gill smear staining for diagnosis of amoebic gill disease. Bull. Eur. Assoc. Fish Pathol. 19: 186-189.

Accepted 6 April 2004 